International Journal of Engineering \& Technology, 9(2)(2020) 299-313
International Journal of Engineering \& Technology
SPC
Website: www.sciencepubco.com/index.php/IJET
Research paper

\title{
Optimal sizing and positioning of grid integrated distributed generator: a review
}

\author{
Arpita De * \\ ${ }^{1}$ Department of Energy, PhD Student, Maulana Azad National Institute of Technology, Bhopal \\ *Corresponding author E-mail: arpita.1802@gmail.com
}

\begin{abstract}
The ever-growing population and globalization have resulted into an increase in demand for power. Additionally, ecological concerns like an unnatural weather change have constrained us to locate new and different substitutes to the current conventional sources of energy. To provide a solution to this crisis of energy in a way that is environment friendly, we have focused our attention towards making renewable energy resources as an alternative to currently employed sources of power. This paper contains extensive study on different Distributed Generation (DG) sources, comparing their merits and demerits also comprising of the impact when added to an already existing AC power grid. Accordingly, the planning methodologies have been discussed which will help us in determining which type of DG suits best to our requirement. This paper also contains the review of optimal placement techniques and sizing methodologies for DG system in grid networks, which are together known as Hybrid Energy Systems (HES).
\end{abstract}

Keywords: Renewable Energy Sources (RES); Distributed Generation; Hybrid Energy Systems; Optimal Placement Techniques; Sizing Methodologies.

\section{Introduction}

The concentrated power age has been available for quite a while. These frameworks use ordinary conventional assets for power age. In any case, overall desire to decrease reliance on petroleum products and moderate atmosphere changes has expanded strain to change to alternative sources of Energy. Distributed Generation (DG) which amounts to small power sources associated close to customer terminals are developing as an alluring substitution. DGs offer a handy solution and greater condition well-disposed choice by giving enough chances to RES based advancements, for example, wind, sun oriented, biomass and so on. Energy sources apart from the conventional energy assets, for example, sun oriented and wind are copiously accessible in nature and thusly have pulled in different energy producing manufacture segments to produce such power on a substantial scale.

Reconciliation of DGs influences current framework performance from various perspectives. By the discontinuous nature and vulnerability related with RES based DGs creates extra difficulties in framework planning. DG can be utilized in a segregated route or in an incorporated way, providing vitality to the existing electric framework. In Distribution frameworks, DG can profit customers and in addition utilities, particularly in locales where the conventional sources aren't conceivable or where there are lacks in the transmission framework.

The vast majority of inexhaustible based DG units specifically create Direct Current (DC) or variable recurrence/voltage Alternating Current (AC) yield control and henceforth Power Electronic Devices (PEDs) have turned into the key components with the end goal to understand the Micro Grids (MGs). As a result of their closeness to various sorts of burdens (i.e. AC and DC), the DG units, for example, the Fuel Cells and the smaller scale turbines can be utilized to give Combined Heat and power (CHP) generation with enhanced by and large effectiveness.

With segments associated with the DG units, for example, energy components, controllable yield forces to meet the heap transient necessities are likewise clarified in this investigation. The wind turbine and PV cluster based DG units are normally controlled with maximum power point tracking (MPPT) towards augmenting their energy generation. In this paper the point of focus is over Solar photovoltaic and its Power stability and Power Quality issues.

There are two particular strategies for solar based power generation to be specific solar photovoltaic and concentrated solar thermal. Solar Photovoltaic (PV) plants straightforwardly changes over daylight into power with no pivoting machine. The alluring aspects of PV frameworks are measured quality; low upkeep and task cost, low weight, ecological neatness etc. are obviously itemized in different research papers which are incorporated underneath. Different control strategies are additionally talked about, which will be reasonable for legitimate running of the plant. Section 2 explains the different definitions as to how we can define the term Distributed generation in terms of location, capacity or both. Section 3 explains about the various technologies which can be used in creating a distributed generation. Section 4 elaborates various advantages of distributed generations. Section 5 explains the main agenda as to why we should be using Renewable based DG's in the first place. Section 6 elaborates challenges of using distributed generation systems. Section 7 justifies the methodologies involved for integrating DG with the grid. Section 8 explains all about Hybrid Energy Systems, there planning techniques, their control 
management, technical factors that are concerned with HES usage. Section 9 summarizes the whole of the quintessence of the paper in the form of conclusion.

\section{Distributed generation}

In the present situation, world's significant vitality necessity is being fulfilled by the preexisting sources of energy (like coal, gaseous petrol, oil and nuclear energy) which are centralized. The world has been responding to the ever growing need of energy demand by trying to find out the alternative sources of energy which could balance the need in a more cost effective fashion. This has led to an increased number of small sized generation plants, directly connected at the consumer end terminals. Such an arrangement is known as Distributed Generation. The technological advancements and change in economy as well as the environmental factors have been the key factors in global inclination towards Distributed Generation.

Their development arose because of the following reasons:

1) Worries over beginning setup expenses of central power plant frameworks and furthermore because of concerns related to environmental factors.

2) The expanding age, disintegration, and limit imperatives upon transmission and lines used for distribution of mass power.

3) Relative climb in economy of large scale manufacturing of smaller apparatuses when contrasted with overwhelming assembling of bigger units and on site construction.

4) Higher by and large complex nature and aggregate costing for administrative oversight, levy organization, and metered charging.

The innovations utilized under DG can be: small gas turbines, Micro-Turbines, power devices, wind and solar energy, bio-mass and so forth. It tends to be utilized in two separate routes either to fulfill nearby customer's interest or in a consolidated manner to supply energy to the rest of the grid system. It can be of utmost importance to those consumer sites where central generation is impractical or the power cannot be transmitted to such remote locations.

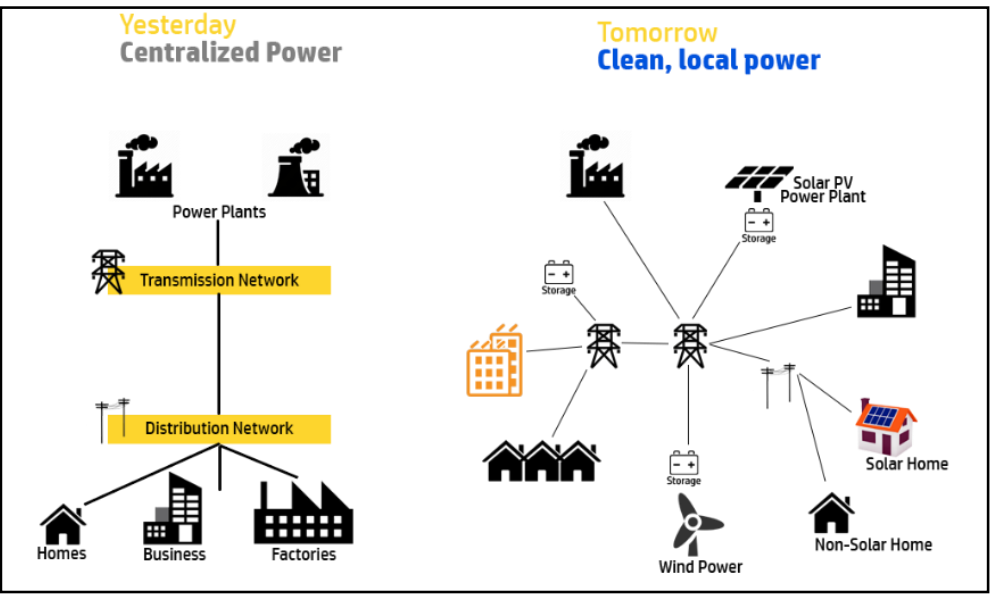

Fig. 1: Centralized Power Generation V/S. Distributed Power Generation.

\subsection{Definition of distributed generation (on the basis of location)}

Power generation source associated specifically to conveyance organize or on client side of meter is one of the key wordings characterized by Ackermann et al [1]. Another announcement was proposed by Borges and Falco et al [2] which characterizes DG's as little producing units introduced near load focuses. All in all terms as depicted by IEA [3], they can be named as producing plants serving a client on location or offering help to conveyance organize associated with matrix at dispersion level voltages.

\subsection{Definition of distributed generation (on the basis of capacity)}

As indicated by EPRI [4] these can be named as Generation sites with a limit fluctuating from a couple of kilowatts up to 50 MW. Anyway according to CIGRE [5] they are each one of those generation units with a most extreme limit of 50 MW to 100 MW, which are normally associated with the distribution system and which are neither centrally planned nor dispatched. According to IEEE [6] standards they are power generation facilities which are particularly smaller than the central generating plants as to permit interconnection between points in the power framework.

\subsection{Definition of distributed generation (on the basis of location and capacity)}

From the perspective of Doni et al [7] these are power generation or storage locales commonly going from not exactly a kilowatt to many Megawatts that isn't a part of extensive central power framework and is found near the heap. While, as indicated by Chambers et al [8] these are small generation units of 30MW or less and situated close client end. Weighing out the pros and cons of the above statements it can be summarized that distributed generation is a form localized generation units having small capacity sufficient enough to bear the needs of localized usage, which often comes in handy when placed directly or near to the point of usage i.e. at the customer's end (at distribution site). From now on it can likewise be named as on site generation, scattered generation, embedded generation. These frameworks can contain different generation and storage parts; in this example they are alluded to as Hybrid power frameworks. 


\section{Types of DG's}

During the introduction of Distributed Generation in the energy market, mostly small sized gas turbines and also diesel generators were commonly used. However, due to the ever increasing fuel cost other sources of energy like fuels cells, along with Solar and Wind energy harvesting techniques were slowly being employed in place of traditionally occurring energy providing setups. This move was likewise made conceivable in light of the advancements in the field of sustainable power source extraction strategies. The DG techniques were then classified as Renewable Energy based and Non-renewable energy based.

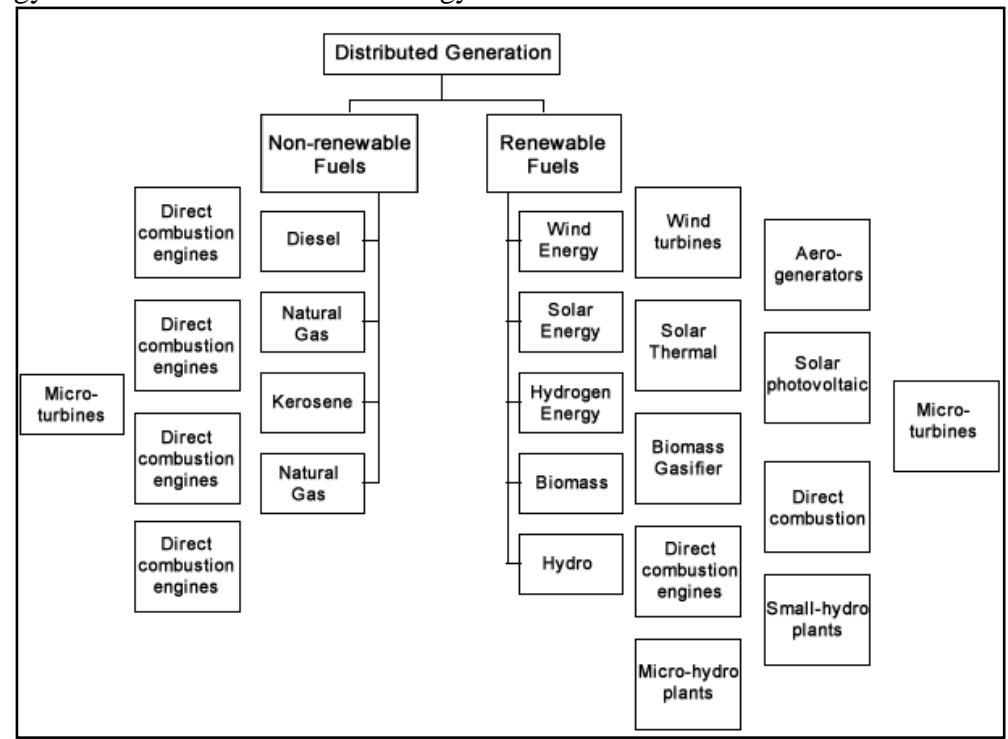

Fig. 2: Bifurcation of Distributed Power Generation.

\subsection{Non-renewable energy based distributed generation sources}

One of the first technologies that introduced the concept of Distributed generation was the Diesel generator Sets (commonly called as DG sets). Distributed non-renewable energy incorporates technologies such as reciprocating (internal combustion, steam and Sterling engines), small turbines (MTs) and combined heat power. Although not wholly advisable, fossil fuels can be used for distributed generation (DG) in areas with highly unpredictable renewable sources or where the available renewable energy technology is not matured enough for reliable operation. Since the size of non-renewable distributed generators is much lesser than large-scale stand-alone conventional power plants, pollutant emissions and fuel costs are lesser.

The advancements in technology have introduced two new fossil fuel technologies i.e. Micro sized turbines and fuel cells.

\subsubsection{Micro turbines offer a few potential advantage contrasted with different advancements for small scale power generation,} including

Few moving parts, smaller size, lightweight, more prominent productivity, bring down discharges, bring down power expenses, and chances to use waste fuels. Petroleum gas is utilized as essential fuel. Waste heat recovery can likewise be utilized with these frameworks to accomplish efficiencies more noteworthy than $80 \%$. Its advantages are little size, low capital costs, low operations and maintenance expenses, and programmed electronic control, small scale turbines are required to catch a huge offer of the distributed generation.

\subsubsection{Fuel Cells can work at a proficiency of about $60 \%$, changing chemical energy into power [9]}

These contribute fundamentally to the cleaner condition; having fewer emanations with their results basically being heated water and carbon dioxide. On account of their modular nature, these energy components can be set at or close to load centres bringing about funds of transmission organize development. These devices can give elite performances, dependability, sturdiness and ecological advantages; a high venture cost still is the significant hindrance against huge scale up and value addition to DGs.

\subsection{Renewable energy based distributed generation sources}

These are direct inverse to regular energy resources (oil, flammable gas) which are region concentric. The renewables involve photovoltaic (PV), wind, hydro, geothermal, tidal and bio fuel.

Two reasons with respect to why this type of energy is being tapped widely is that they are replenishable and are accessible in great sums, scattered geologically [10]. There has been a critical increment in deploying of sustainable based DGs to grid, because of decrease in expenses of generation and capacity along these lines empowering expansive scale arrangement. Furthermore, customary framework design is getting changed logically to consolidate micro grids with traditional distributed generation grids. Predominantly there are PV and wind energy sources. Wind energy exploitation has demonstrated huge overall development and is likewise one of the leading carbon free advances. Be that as it may, its ceaseless accessibility is a noteworthy issue making them less reliable for independent applications. Effective energy storage advances have been produced as a choice to decrease the disparity between demand and supply.

\subsection{Energy storage technologies}

Meteorological reliance of PV and wind energy sources makes a hole between power from these sources (Supply) and load (Demand). To defeat these issues [11], here and now distributed energy sources (DES) dependent on cutting edge innovations, for example, 
superconducting magnetic energy sources (SMES), super capacitor (or ultra-capacitor) energy sources (SCES or UCES) and flywheel energy sources (FES), emerge as a potential option with the end goal to adjust any prompt difference in demand and supply in the grid. Aside from pumped hydro, other capacity advances require enhancement both regarding execution and in-addition cost. Energy Storage offers an answer for control stochastic nature of sustainable power source constructed DG's without being reliant on petroleum product based advancements for back up. A few precedents are pumped hydro, compressed air energy storage (CAES), Super capacitors, SMES and flywheel which can be quickly deployed yet have restricted limit. Battery energy storage is a standout amongst the most mainstream utilized for large scale deployment on grid.

\section{Advantages of distributed generation}

Dispersed resources can enhance the productivity of providing the consumers with electric power. Often the transmission of power from a power plant to a consumer squanders generally 4.2 to 8.9 percent of the power as a result of maturing transmission gear, conflicting authorization of reliability guidelines, and developing congestion [12-19]. In the meantime, clients regularly experience the ill effects of poor power quality - varieties in voltage or electrical stream - that outcomes from an assortment of variables, incorporating poor switching operations in the system, voltage plunges, interferences and system disturbances from loads. Generally speaking, DG defenders feature the wastefulness of the current huge scale electrical transmission and distribution network.

Different advantages of DG over Centralized Power Distribution are:

1) Technical benefits

2) Economic benefits.

3) Environmental benefits.

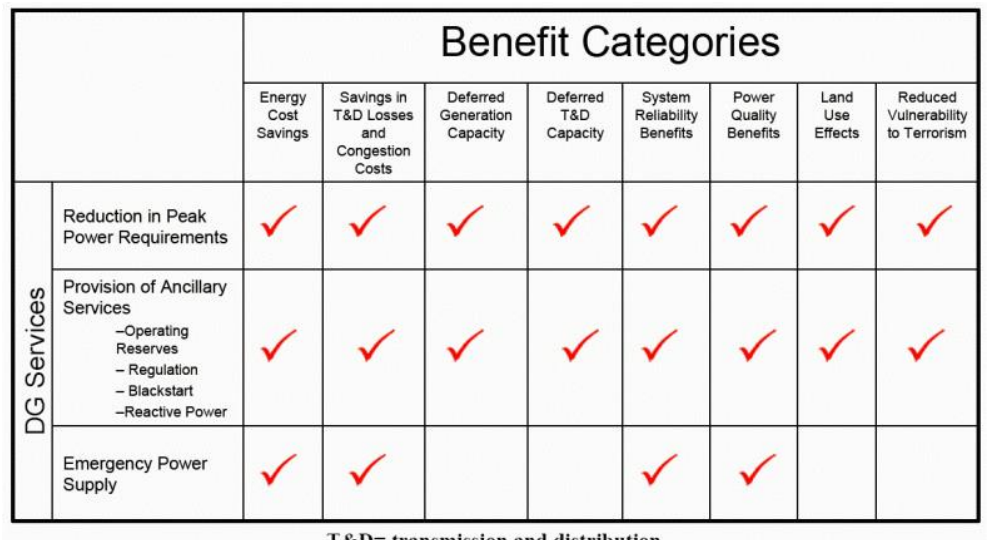

Fig. 3: Advantages of distributed generation.

\subsection{Technical advantages}

- Line losses can be drastically reduced upon proper placement of DG's near heavy loads.

- Voltage profile is improved upon its application.

- Improved power quality.

- The grids reliability is increased.

- Transmission and Distribution line congestions are reduced.

\subsection{Economic advantages}

- Productivity is enhanced.

- Reduction in Health Care investments.

- Reduction in fuel prices.

- Lower operation and maintenance cost due to small size

- Investments can be redirected to upgrading of technologies.

\subsection{Environmental advantages}

- Lower greenhouse gas emissions.

- Helps in increasing diversity of energy resources of a location.

- Insulates the economy from price shock, fuel interruptions.

- Increase in investing into green technology.

\section{Objectives of distributed generation integration}

Regarding the enhancement of reliability and efficiency, joining of distributed generation (DG) into distribution network has increased critical enthusiasm for late years. Be that as it may, existing distribution networks were not planned considering vast scale infiltration of DG. Because of the expanding entrance of DG [20], a few specialized difficulties may emerge which incorporate voltage control, control quality and protection issues, etc. The objectives must henceforth be laid down clearly in the planning phase to rule out any of such above written explanation. These can be broadly categorized into the following categories: 


\subsection{Increasing the proportion of DG supplied power to the grid}

According to Chedid, Wang and Katsiagnis [21-24] reduction in fossil fuel usage is one of the primary reflections of integrating more DG into the grid. The greenhouse gas emission can be clearly reduced with its application. Being eco-friendly is also one of the traits of renewable DG which makes it a competitive contender in power market. Emission is primary factor while calculating the size of DG installation units. Economic and environmental objective also have a say in this decision making process.

\subsection{Maximization of system reliability}

The power market is getting highly competitive these days. This has created tremendous pressure on the suppliers to produce good quality power and more importantly one which can be reliable i.e. present in times of need.

Islanded operation of DG is not allowed because of the following reasons [25]:

- Increasing frequency and voltages.

- Safety of operating personnel is jeopardized.

Henceforth, all DG sources remain de-energized in case a fault occurs. Borges et al [2] calculated that the reliability benefits grow tremendously by considering DG sources as constant voltage sources. Preglj et al [26] has justified that positioning the protection devices through genetic algorithm can significantly affect reliability. In a similar case Ant colony algorithm can be used, as suggested by Wang and Chann Singh [27]. These above stated measures can be considered fixed because they are concentrating over conventional DG's. When renewable based DG's are used reliability impacts are not predefined because the power they generate varies over different geographical and weather conditions. During these conditions the dependency on storage technologies comes into picture.

\subsection{Reducing the cost of investment and operation}

Integrating DG's with grid surely reduces the burden on Central power station to supply power to load. But it definitely comes with additional costs for installation, maintenance and the need for protection equipment for the DG apparatus. Different approaches have been suggested by various authors to minimize these extra costs, some of which are explained below:

- Gautam et al [28] has developed a more economic approach to analyse the cost related issues where he uses social welfare optimization techniques (based on customer perspective) and profit maximization techniques (based on utility perspective).

- Again mentioning, Chedid et al. [21] and Wang et al. [22] also have figured a multi target mix for deciding ideal portion of solar and wind energy based DGs and storage batteries for grid connected hybrid power system. In this equation numerous point of limiting annualized capital expense alongside augmenting maximizing reliability and decrease in emission have been focused on.

The economic investigation performed by above authors obviously supports to run with the idea of grid connected DG's. Anyway when DG with sustainable power sources are viewed then the establishment cost goes up higher which can be considered in light of the additional advantage of clean energy that they are giving due to storage, the issues related with discontinuity of RES are managed.

\subsection{Reduction in system losses}

Being available near load centres, it essentially diminishes the aggregate expense of transmitting power at such vast separations which straightforwardly lessens the measure of intensity being squandered in resistance losses of the line. Consequently suitable size and area of DG establishment assumes a key role to lessen the most extreme measure of losses in the power system as reported in the literatures [2933]. Among these a portion of the central point have been placed up in an examination directed via Carpinelli [34] which thinks about an arrangement of situations of power generation from wind based DGs with their probabilities of occurrence. A powerful method to investigate this has been caught by Quezada et al. [35] where in actuality of various DG technologies, penetration levels, DG dispersion and location and reactive power control methodologies on system losses has been contemplated. It has been inspected by the creators that breeze turbines have slightest positive effect on losses because of their high inaccessibility. Energy from PV, however inaccessible treats day by day load variations more efficiently. The above expressed two creators have likewise considered the effect of reactive power control abilities of DG on system losses.

\subsection{Improving the voltage profile}

Coordinating DG's with grid can raise the system voltage marginally. The principal approach utilizes weighting factors dependent on significance and criticality of various loads to assess voltage profile enhancement record. The second method figures the index on how the voltage profile is in closeness with the nominal voltage levels.

Abou et al. [36] have structured a multilevel problem where in enhancement in voltage profile has been considered alongside weighting factors related with different goals as reason for examination of enhancing voltage level up to a coveted level.

\section{Repercussions of using distributed generation systems on different factors}

Conventional grid systems were designed considering normal operational flow of power from generating stations straight to load centres without any intermediate point of power source. Henceforth if fluctuations in output or backward flow of power occur due to malfunctioning of DG, severe impact can be observed on overall transmission, distribution system and load centres. The impacts of DG can be described as follows:

a) Loss in power:

They can cause harmful impact on both active as well as reactive power as compared to capacitor bank malfunction which can only trigger reactive power loss. With proper positioning and sizing techniques these power losses can be greatly reduced. Such a location is called optimum location. On these locations reactive power can be compensated so that voltage can be controlled easily without having any further loses in line. These can also act as spinning reserves in case of main power station malfunctioning [37-38].

b) Power Quality:

It can be defined in terms of closeness of the normal characteristics being aligned with the ideal voltage and current wave form. For this to take place, the system operators ensure a minimum short circuit capacity. For example, where there arises difficulty in voltage support, 
distributed generation can be of high use because they generally lead to a high rise in voltage [39-47] also mention a positive impact of Distributed generation on power factor corrections

c) Excess Voltage and voltage fluctuations:

If there is congestion in DG units over the line then there can be a back-flow of power in case of power gap between the feeder lines. Fluctuation from the normal working conditions of a single distribution transformer supplying power to an entire block of area as explained in [48-51] can take place if there is a difference in voltage profile of the feeder. This change can occur more frequently when renewable energy based distributed generation is coupled to the main feeder.

d) Reliability:

DG were introduced to the grid mainly to serve at those remote locations where feasibility to send power to the remote locations were compromised. It was thus of prime importance to maintain reliable source of power supply for the customers. So that interruption and power outages may not create severe economic impact on the utility [52]. Conventionally to analyse the reliability at the distribution level is far more complicated and costly when done at transmission and distribution level as compared to generation sites because they are more dispersed. In such cases DG can be used as a backup thereby increasing the reliability of the system.

e) Protection apparatus:

Fault on DG side can cause the backflow of power hence additional care has to be taken in cases of fault clearance. This can be explained in following two examples [53]:

- For faulty operation, the short circuit current is provided by both central power station and the DG which can readily cross the upper limit of breaker capacity, thereby causing damage to the power system equipment.

- Depending on the location of distributed generation and fault, power flow can cause reduction in feeder current from lines which can result into the situation remaining undetected by the actuator sensors of the protection equipment.

The above two explanations clearly justifies the need of protection co-ordination which are flexible in controlling bi-directional flow of power.

f) Harmonics:

Need to inject harmonics into the grid arises, when renewable energy based DG are integrated into it. IEEE 1547 interconnection standard [54] states the limit on harmonic distortion caused due to interconnection. Type and severity of injection depends upon power converting technology and the pattern of interconnection. Harmonic distortion can also be limited by improving converter design with better filters.

g) Reactive power management:

This can be severely impacted because DG can supply reactive power without electronic interfaces [55]. Different inverter technologies are employed to consume and supply reactive power to the system. Additional controlling techniques are needed for smooth functioning of the mechanism.

\section{Planning methodologies of dg integration}

To tackle with the above problems faced due to DG Integration, proper size and location of DG integration has to be calculated. This has been a major challenge for all the power system planners. Extensive research has been done on this topic and a number of approaches have been laid down in many literatures, which are described as follows:

\subsection{Analytical approach}

These methodologies make utilization of numerical mathematical conditions which should be settled for optimizing purposes. As the unpredictability of the system increments, so does the numerical complexity to understand such conditions. A nitty gritty research has been done over the explanatory methodologies in concentrates explained in [56-63]. The impact of static load model in deciding ideal size and location of DG was considered by Gozel et al [64]. Finding ideal area without considering the size of DG establishment was done by Nehrir [60] because of Unity control factor limitation. Willis [59] then again recommended to introduce DG of size of roughly $2 / 3$ limit of the age at $2 / 3$ of length of the feeder. A portion of the basic logical methodologies are:

- Analytical approach on the basis of $2 / 3$ rule:

This technique targets to minimize losses in feeder [59]. The positive points about this technique are that it's simple and helpful in capacitor placement and its solution helps in minimizing average power losses. The demerit is that we get an approximate solution rather that exact, also it cannot be applied directly if the size or characteristics of DG remains unknown.

- Analytical approach based on exact loss formula:

This procedure focuses to limit power and feeder losses as recommended by Gozel et al [64]. It's simple and easy to use and gives quick results because of its non-iterative nature. It contains no convergence problem. However it may give erroneous solution for a real life situation and also its non-robust in nature.

- Analytical method with fuzzy logic

Devi and Subramanyam et al. [65] have clearly stated that this technique focuses on active branch currents to minimize the losses. This technique clearly finds its merits in locating the exact position of DG which reduces power loss to $100 \%$ thus improving voltage regulation. But it also contains a limitation that it can only be applied to a single DG unit in the entire grid and also the computational techniques are slow.

- Analytical method based on current injection

Also Gozel and Hocaoglu et al. [64] mentioned in their literature that this technique is based on sensitivity factor correction targeted specifically to maximize profitability. Being non iterative in nature it has no convergence issues. Reduction in power loss is maximum in this condition under normal DG operation.

\subsection{Meta-heuristic approach}

It is an iterative procedure which utilizes execution of essential advances, whose outcomes goes about as manual for its ensuing heuristic [66] with the end goal to effectively locate the ideal or close ideal answers for optimization of grid incorporated DG benefits by discovering the right position and size of DG sets. This methodology uses the most recent artificial ideas to locate the precise answer for optimization problems. A portion of the calculations that influence utilization of heuristic ideas to incorporate Stimulated Annealing (SA), GA, Tabu Search (TS), Particle Swarm Optimization (PSO), Ant Colony advancement (ACO). A portion of these are clarified underneath: 


\section{- Tabu Search (TS)}

This procedure was utilized by Nara at al. [67], Golshan and Arefifar [68] to improve DG size and areas through ground-breaking advancement device that can avoid nearby minima by utilizing an adaptable memory system [69,70]. This procedure widely investigates its memory structures to successfully and monetarily guide the inquiry to attractive regions in the solution space. Be that as it may, the capacity to demonstrate optimality of Golshan arrangements is lost and inexact and remaining arrangement are obtained by means of this strategy.

- $\quad$ Particle Swarm Optimization (PSO)

It is a swarm insight strategy utilized in displaying social attributes to control swarms of particles towards the most powerful regions of the pursuit space [71]. Strikingly, PSO received by Ardakani et al. [72] is effortlessly utilized and ordinarily results in quicker convergence rates than Genetic Algorithms (GA) be that as it may, its application is restricted in light of the fact that it is just productive in taking care of unconstrained optimization issues [73].

- Ant Colony optimization (ACO)

It emulates the calculations utilize a populace of Ants, also called colony to all in all take care of the optimization issue under thought. Every Ant scans for least cost feasible arrangements dependent on its private data and the data accessible in the neighbourhood hub it visits. Truth be told, every Ant of the colony is sufficiently able to locate a possible arrangement; anyway an aggregate cooperation among these Ants would yield better quality outcome [74]. Utilizing ACO calculation [75] taking DG unit's consistent power sources, considered minimization of DG venture cost and the total activity cost of the system as the point the capacity decides the ideal number and position of DG sources in distribution systems.

\subsection{Artificial intelligence}

In AI, Genetic Algorithms (GA) is an exceptional class of transformative calculation which utilize strategies enlivened by evolutionary mechanism, for example, selection, crossover and mutations $[76,77]$. They are effective advancement look methods utilized in finding the correct or close ideal arrangements in multi-objective optimization problems. Its applications can be found in a few teaches for instance computational science, engineering, arithmetic and so forth. A hereditary search is done before an arbitrarily created initial population, covering the whole scope of conceivable outcomes. The validity of every person in the population in every generation is then figured and altered to make another gathering of better arrangements. These as of late processed population are utilized for the following cycle of the iteration that ends either when an agreeable level of fitness has been accomplished or when a maximum number of generations have been produced in the population.

Some of the methods employing Artificial intelligence are as follows:

- A three step procedure, based on Genetic Algorithms (GA) and Decision theory (DT)

The essential target of utilizing this system is to limit expenses of network investments and losses. This function works with the similarity of limiting the technical constraints as recommended via Carpenlli et al. [78]. The upside of utilizing this strategy is that the method outfits the most ideal DG siting and estimating, considering vulnerabilities presented by DGs.

- Value Based Planning Methods

The point is to limit the client's interruption costs and the power losses. The target work is obviously laid in the writing proposed by Celli and Pilo [79] and Tang et al. [80] and centers over its capacity to investigate every single conceivable blend on the arrangement set looking for other non-substandard arrangements in parallel. There is a downside in this technique as it requires a considerable measure of convergence time additionally now and again it might prompt untimely convergence.

- Combination of Genetic Algorithm Techniques

Minimization the system losses and amplify a benefit/cost connection is the sole thought process behind this mix set of genetic algorithm. The additional favourable position here is the utilization of probabilistic guidelines instead of deterministic principles for computational purposes. Additionally these are less vulnerable against local noise as examined and mentioned earlier by Borges and Falco [2].

\subsection{Genetic algorithm hybrid approach}

The real difficulties of utilizing the genetic algorithms have driven numerous analysts to trust that the mix of GA and one other optimization systems together would be better arrangement. GA is great at discovering great global solutions yet not all that effective in deciding without a doubt the ideal [81]. Procedures that are very powerful in finding absolute optimum a restricted minimum when joined with GA will enhance the effectiveness of GA alongside defeating the absence of robustness in the other search methods. A portion of the precedents are expressed as follows:

- Some of the creators like Gandomkar et al. $[82,83]$ have utilized Tabu search in the generation period of GA to dispense with the disadvantages of the established Simple Genetic Algorithm (SGA).

- In a comparable design, Hereford Ranch calculation [85] receives sexual differentiation and specific breeding while at the same time picking parents for hereditary string as a method for enhancing the SGA for a superior arrangement.

- Also, another half and half calculation of hereditary and recreated toughening was proposed [86] for computing the DG size and site in appropriation systems. The aftereffects of the cross breed shown its viability over that of SGA regarding quality and number of cycles.

- Combined GA-OPF: Sao et al. [87] recommended this blend to limit the limit of DG. This methodology turned out superior to SGA regarding arrangement quality and number of iterations required to figure the solution.

- Non-ruling arranging with GA algorithm: Again Hagifam et al. [85] planned this half and half way to deal with limit the monetary cost index, technical dangers and financial dangers. This ended up being a fruitful basic leadership instrument for risk management in distribution network incorporated with DG. In any case, this strategy isn't as powerful as joined GA-OPF clarified previously.

\section{Hybrid energy systems}

In the wake of talking about all the fundamental terminologies and key elements identified with joining of distributed generation systems to lattice, we will center around the framework so acquired after combination frequently called as Hybrid Energy Systems (HES). The hybrid energy framework predominantly involves sustainable power source generators (AC/DC sources), non-renewable generators (AC/DC sources), power conditioning links, stockpiling, load (AC/DC) and now and again may incorporate grid. A general crossover vitality framework setup has been delineated in figure as demonstrated as follows. 


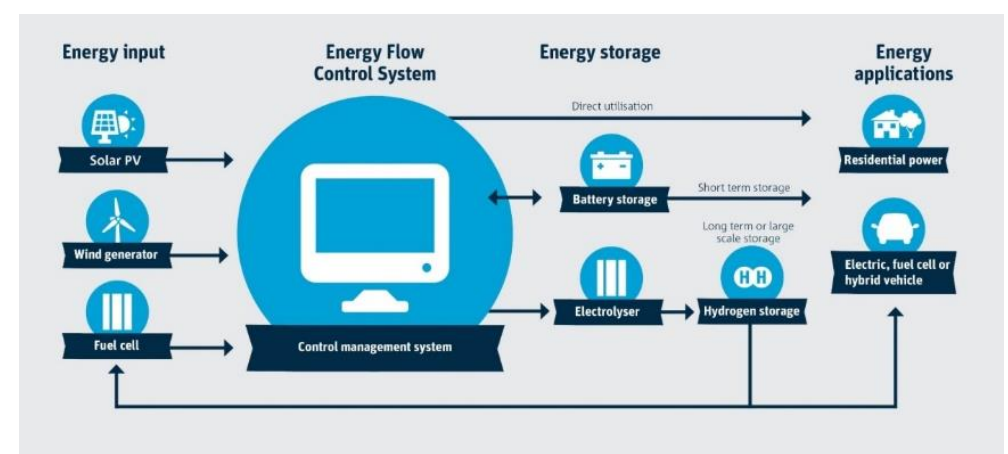

Fig. 4: General Crossover Vitality Framework of Distributed Power Generation.

\subsection{Configurations of HES.}

The determination of a specific design relies upon the kind of utilization. The distinctive designs alongside their configuration, demerit, application alongside the particular loads and sources can be additionally condensed into the accompanying:

\subsubsection{DC coupled}

In this sort of setup both source and loads are DC. This arrangement does not require any sort of synchronization. Be that as it may, since inverter is required to supply capacity to load, this setup turns out to be totally pointless when the inverter leaves out of service. These are especially utilized for low voltage DC application on smaller scale grids [88].

\subsubsection{Power frequency ac coupled system}

In this kind of design both source and load are AC. In such a setup, protection of all the power hardware is substantially simpler. Anyway coupling indicators might be required to get a smooth stream of intensity. Customarily it is connected to AC small scale grids [89].

\subsubsection{High frequency ac coupled system}

AC sources working at different frequency when joined with heaps of high frequency nature comprises this kind of arrangement. Its benefits are restricted to high effectiveness of grid, with decreased size and weight of warmth dispersal equipment's. Be that as it may, this kind of arrangement needs to shoulder heat dissemination losses because of the nearness of high frequency converters. It discovers its application in planes, sub-marines and space station applications [90].

\subsubsection{Hybrid coupled system}

In the event that both the sources and loads are a mix of AC and DC then this kind of arrangement is known as hybrid coupled framework. This kind of arrangement is most adaptable in contrast with different setups; consequently it very well may be planned with greatest productivity at a diminished expense. Control and energy management can be of worry as the two kinds of burdens are available AC/DC. Greater part of its applications are in observed in conventional networks [91]

\subsection{Evaluating criterions for designing HES}

Summarizing the key components from the literatures [92-96], following are the primary criterions taken into consideration while designing HES. These points can be pictorially shown as given in figure:

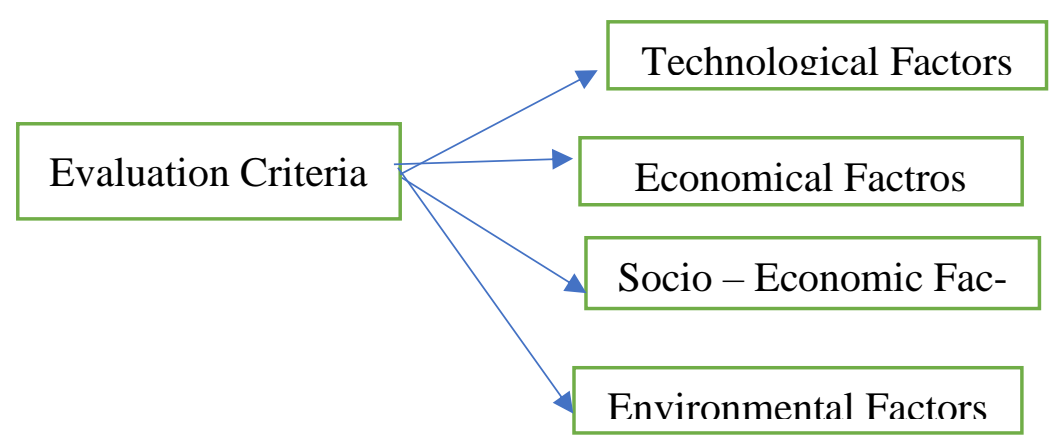

Fig. 5: Various Criterions for Evaluation of Hybrid Energy Sources.

\subsubsection{Technological factors}

- Feasibility: There ought to be a plausibility of implementing HES.

- Risk: Ensure the likelihood of actualizing HES by ascertaining the quantity of issues related amid disappointments while testing of the framework.

- Reliability: The standard computes if the technology of HES can be actualized. HES can be tried in lab or can be performed in the pilot plants, or it could be as yet enhanced before implementing before simulation, thinking about different parameters.

- Duration of Preparation Phase: The rule computes the accessibility of the renewable power source potential in the territory, choice to diminish the budgetary resources and achieve the base expense. 
- Duration of Implementation Phase: It assesses the pertinence of HES choice to achieve the base expense.

- Community and consistency of execution: It manages assessment of task and execution of HES.

- Low specialized skill: It assesses the focused correlation between the unpredictability of the innovation considered and limit of local errors.

\subsubsection{Economic factors}

- Implementation Cost: It investigations the aggregate expense of energy interest with the end goal to be completely operational.

- Availability of Funds: It assesses the national and worldwide wellsprings of funds and furthermore considers the financing given by the administration.

- $\quad$ Economic esteem: It makes a decision about the proposed sustainable power source alternative. It utilizes designing monetary methods like Present worth (PW), Internal Rate of Return (IRR), and Benefit/Cost investigation and playback period (PP).

\subsubsection{Socio-political factors}

- Compatibility with national energy strategy destinations: It breaks down the incorporation of the national energy policy and the concerned sustainable power source alternative. It quantifies the level of assembly between the two. It likewise thinks about strategy of public information.

- $\quad$ Political Acceptance: It thinks about the agreement among opinion of leaders for proposition of sustainable alternative energy.

- Social Acceptance: Its principle parameters are open support. It thinks about accord among social parameters, likewise considering maintaining a strategic distance from the responses of specific vested parties for not executing sustainable power source frameworks.

- Labor Impact: It assesses every single other option based on effect on labour. It is identified with immediate or indirect employment, surveying the likelihood of aberrant formation of new expert figures.

\subsubsection{Environmental factors}

- Pollution Emission: it quantifies the comparable outflow of $\mathrm{CO} 2$ which results as combustion by-product, fluid wastes which are identified with secondary products. It likewise incorporates the sort and nature of emanation and costs identified with treatment of waste.

- Land Requirement: It is one of the essential variables of speculation into energy. Solid interest can prompt substantial costs which thus makes it unfeasible for investment.

- Need of Waste Disposal: It assesses the harm caused because of waste item administration on the earth. The sustainable power source option can be evaluated to decrease the harm on nature.

\subsection{Various Sizing Methodologies for HES.}

The dominant factor in determining the size of HES for its installation purpose is the climatic condition of that particular geographical area. The major issue with this is that the data varies continuously with time. For extracting the maximum benefits from Solar or Wind based HES we need to figure out the characteristic pattern of this data in the form of time series or statistical form as depicted in figure. Sizing criteria has become of primary concern because other factors such as cost minimization, reliability improvement, reduction in emission is also considered

A comparison between the different meteorological data generation techniques is given in table below.

Table 1: Various Meteorological Data Generation Techniques

\begin{tabular}{lllll}
\hline $\begin{array}{l}\text { S. } \\
\text { No. }\end{array}$ & $\begin{array}{l}\text { Data genera- } \\
\text { tion technique }\end{array}$ & Input & Merit & Demerit \\
\hline 1 & $\begin{array}{l}\text { Time series } \\
\text { meteorologi- } \\
\text { cal data }\end{array}$ & $\begin{array}{l}\text { weather data on hourly basis is } \\
\text { updated }\end{array}$ & $\begin{array}{l}\text { Raw data is directly used which incorpo- } \\
\text { rates variability factor so the design can be } \\
\text { made more accurately. }\end{array}$ & $\begin{array}{l}\text { Location which becomes a tedious task for } \\
\text { which } \\
\text { accessing remote locations }\end{array}$ \\
& $\begin{array}{l}\text { Statistical me- } \\
\text { teorological } \\
\text { data }\end{array}$ & $\begin{array}{l}\text { Weather data can be syntheti- } \\
\text { cally generated on monthly av- } \\
\text { erage value of data. }\end{array}$ & $\begin{array}{l}\text { When weather data becomes unavailable, } \\
\text { this method saves time for generating the } \\
\text { same in simulation model. }\end{array}$ & $\begin{array}{l}\text { The system so obtained will be less } \\
\text { sensitive to system parameters. }\end{array}$ \\
[101- \\
106]
\end{tabular}

All the sizing methodologies can be broadly classified into the following categories:

- Graphical Methods.

- Probabilistic Methods.

- Analytical Methods.

- Iterative Methods.

- Artificial Intelligence Methods.

- Hybrid Methods.

A brief description about all the methods is given below according to various studies conducted by different authors:

\subsubsection{Graphical methods}

A graphical development strategy is shown by [107] for computing the measure of independent PV-Wind framework. The author trusts that average value of demand must be fulfilled by the average value of solar radiation and twist speed for an unmistakable size of PV generator and wind turbine. Regular variety is likewise considered for considering the accessibility of intensity that can be conveyed in various seasons. In light of the examination a measuring bend is created for different PV generators and wind turbines. Contingent upon the measure of accessible information a sharper curve can be gotten. Studies were led relying upon the kind of info parameters utilized; a short diagram is given in the table beneath. 
Table 2: Summary of Graphic Construction Methods

\begin{tabular}{|c|c|c|c|c|c|}
\hline $\begin{array}{l}\text { Input Parame- } \\
\text { ters }\end{array}$ & $\begin{array}{l}\text { Standalone/ } \\
\text { grid Connected } \\
\text { mode }\end{array}$ & $\begin{array}{l}\text { Energy } \\
\text { Sources }\end{array}$ & $\begin{array}{l}\text { Value for } \\
\text { which optimi- } \\
\text { zation was } \\
\text { performed }\end{array}$ & Method Used & $\begin{array}{l}\text { Ref- } \\
\text { er- } \\
\text { ence }\end{array}$ \\
\hline $\begin{array}{l}\text { Monthly aver- } \\
\text { age wind speed } \\
\text { and solar radia- } \\
\text { tion }\end{array}$ & Standalone & $\begin{array}{l}\text { PV-Wind sys- } \\
\text { tem }\end{array}$ & Power balance & $\begin{array}{l}\text { Regular examination was made for variety of interest and source } \\
\text { accessibility for generator amid winter and summer seasons. The } \\
\text { measuring curve is then created }\end{array}$ & [107] \\
\hline $\begin{array}{l}\text { Hourly wind } \\
\text { speed and solar } \\
\text { radiation }\end{array}$ & Standalone & $\begin{array}{l}\text { PV-Wind sys- } \\
\text { tem, Genera- } \\
\text { tor and Bat- } \\
\text { tery }\end{array}$ & Cost of system & $\begin{array}{l}\text { The normal power yields of both the wind turbine and the PV } \\
\text { module were ascertained for a given Loss of Power Supply Prob- } \\
\text { ability, an alternate mix of the quantity of PV modules and the } \\
\text { quantity of batteries was computed. An ideal plan decision was } \\
\text { then made by plotting the measuring curve }\end{array}$ & [108] \\
\hline
\end{tabular}

\subsubsection{Probabilistic methods}

In this technique just a couple of execution parameters are considered consequently this methodology isn't that solid when contrasted with others. Be that as it may, this is the least difficult among all, thus can be utilized for preliminary calculations. In the vast majority of the conditions for remote area the information for PV sunlight based radiation and wind speed is inaccessible. This issue was managed in paper [109] where a sustainable power source framework demonstrate comprising of sun powered, wind and battery stockpiling, which considers the blackouts because of energy variances was produced. Another technique is exhibited in [110] wherein for soundness thought; a given level of entrance is chosen. The generation expenses of the Diesel units are then derived from the expected energy not supplied (EENS) utilizing a unit de-convolution in reverse economic order. Studies were directed relying upon the kind of information parameters utilized; a short outline is given in the table beneath.

Table 3: Summary of Probabilistic Methods

\begin{tabular}{|c|c|c|c|c|c|}
\hline $\begin{array}{l}\text { Input Parame- } \\
\text { ters }\end{array}$ & $\begin{array}{l}\text { Standalone/ grid } \\
\text { Connected mode }\end{array}$ & Energy Sources & $\begin{array}{l}\text { Value for which } \\
\text { optimization was } \\
\text { performed }\end{array}$ & Method Used & $\begin{array}{l}\text { Refer- } \\
\text { ence }\end{array}$ \\
\hline $\begin{array}{l}\text { Probabilistic so- } \\
\text { lar radiation and } \\
\text { wind speed data }\end{array}$ & Standalone & $\begin{array}{l}\text { PV-Wind sys- } \\
\text { tem, Generator } \\
\text { and Battery }\end{array}$ & EENS & $\begin{array}{l}\text { Outages because of primary energy fluctuations and } \\
\text { hardware failure are taken into consideration. To satisfy } \\
\text { this need an upper limit of battery capacity is also con- } \\
\text { sidered. Cost v/s EIR is then calculated }\end{array}$ & [110] \\
\hline $\begin{array}{l}\text { Probabilistic } \\
\text { wind speed data }\end{array}$ & Standalone & $\begin{array}{l}\text { Diesel Generator, } \\
\text { wind generator } \\
\text { and Battery }\end{array}$ & EENS & $\begin{array}{l}\text { Convolution method is used which make use of penetra- } \\
\text { tion level for stability considerations. Production cost of } \\
\text { diesel units is then calculated. }\end{array}$ & [111] \\
\hline $\begin{array}{l}\text { Probabilistic so- } \\
\text { lar radiation and } \\
\text { wind speed data }\end{array}$ & Standalone & $\begin{array}{l}\text { PV- wind and } \\
\text { diesel generator }\end{array}$ & $\begin{array}{l}\text { LLE (Loss of load } \\
\text { expectation) }\end{array}$ & $\begin{array}{l}\text { A recreation technique that gives target pointer to enable } \\
\text { organizers to choose proper establishment locales, } \\
\text { choice of energy types in little disengaged frameworks. }\end{array}$ & [112] \\
\hline
\end{tabular}

\subsubsection{Analytical methods}

In these techniques the span of the hybrid energy systems framework is taken as an element of feasibility and HES are spoken to by methods for computational models. A calculation was proposed by Gupta et al. [113] which is fit for structuring a minimum cost town jolt framework by making the framework a hybrid blend of Solar and diesel generator, which helps in keep up a smooth profile in the midst of low sun oriented radiation. Various different examinations were led relying upon the sort of information parameters utilized; a concise outline is given in the table beneath.

Table 4: Summary of Analytical Methods

\begin{tabular}{|c|c|c|c|c|c|}
\hline Input Parameters & $\begin{array}{l}\text { Standalone/ grid } \\
\text { Connected mode }\end{array}$ & Energy Sources & $\begin{array}{l}\text { Value for which } \\
\text { optimization was } \\
\text { performed }\end{array}$ & Method Used & $\begin{array}{l}\text { Refer- } \\
\text { ence }\end{array}$ \\
\hline $\begin{array}{l}\text { Hourly solar radiation, } \\
\text { producer gas, discharge } \\
\text { rate of water and biogas }\end{array}$ & Standalone & $\begin{array}{l}\text { Diesel, bio-mass, } \\
\text { bio-gas, PV gen- } \\
\text { erator }\end{array}$ & $\mathrm{COE}$ & $\begin{array}{l}\text { Least cost village electrification can be de- } \\
\text { fined easily with this approach, while diesel } \\
\text { generator keeps the output constant }\end{array}$ & [114] \\
\hline $\begin{array}{l}\text { Probabilistic wind and } \\
\text { solar PV data }\end{array}$ & Standalone & $\begin{array}{l}\text { Wind, PV genera- } \\
\text { tor and battery }\end{array}$ & Production cost & $\begin{array}{l}\text { Amount of meteorological data required here } \\
\text { is quiet less, requires less time that Monte } \\
\text { Carlo simulation }\end{array}$ & [115] \\
\hline $\begin{array}{l}\text { Hourly solar radiation, } \\
\text { producer gas, discharge } \\
\text { rate of water and biogas }\end{array}$ & Grid Connected & $\begin{array}{l}\text { Coal, natural gas, } \\
\text { hydroelectric } \\
\text { power plant }\end{array}$ & $\mathrm{COE}$ & $\begin{array}{l}\text { This paper proposed that since the renewables } \\
\text { considered are relatively new, there is a need } \\
\text { to satisfy the reduction in } \mathrm{CO}_{2} \text { emission target }\end{array}$ & [116] \\
\hline
\end{tabular}

\subsubsection{Iterative methods}

Recursive process helps in the evaluation of iterative strategies for HES, these cycles' stops when best setup is accomplished to suit the structure determination. Nikhil and Shubhankar [117] proposed a by and large new methodology dependent on versatile input learning focused towards achieving quicker intermingling of simulation algorithm, which at that point approved utilizing a test setup. In actuality $\mathrm{Xu}$ et al. [118] built up a calculation covering both independent and lattice associated models, where he connected a energy channel to smoothen out the impacts of variances of intensity infused into the grid. Another creator known as Kaldellis [119] presented an iterative system for estimating of HES as a component of aggregate expense. Studies were directed relying upon the sort of info parameters utilized; a short outline is given in the table beneath. 
Table 5: Summary of Iterative Methods

\begin{tabular}{|c|c|c|c|c|c|}
\hline Input Parameters & $\begin{array}{l}\text { Standalone/ grid } \\
\text { Connected mode }\end{array}$ & Energy Sources & $\begin{array}{l}\text { Value for which opti- } \\
\text { mization was per- } \\
\text { formed }\end{array}$ & Method Used & $\begin{array}{l}\text { Refer- } \\
\text { ence }\end{array}$ \\
\hline $\begin{array}{l}\text { Hourly wind speed and } \\
\text { ambient temperature }\end{array}$ & Standalone & $\begin{array}{l}\text { Wind, Diesel gen- } \\
\text { erators and battery }\end{array}$ & $\begin{array}{l}\text { Annual fuel con- } \\
\text { sumption, total cost } \\
\text { analysis }\end{array}$ & $\begin{array}{l}\text { Optimal designing of HES was consid- } \\
\text { ered on the basis of minimum long } \\
\text { term energy cost. }\end{array}$ & {$[120]$} \\
\hline $\begin{array}{l}\text { Hourly solar radiation and } \\
\text { wind speed }\end{array}$ & Standalone & $\begin{array}{l}\text { PV, Wind genera- } \\
\text { tor, battery }\end{array}$ & LPSP, LCE & $\begin{array}{l}\text { Configuration is obtained on the basis } \\
\text { of desired system reliability require- } \\
\text { ment. }\end{array}$ & [121] \\
\hline $\begin{array}{l}\text { Hourly solar radiation, } \\
\text { wind speed and ambient } \\
\text { temperature. }\end{array}$ & Standalone & $\begin{array}{l}\text { PV, Wind genera- } \\
\text { tor, battery }\end{array}$ & $\begin{array}{l}\text { Number of PV panel, } \\
\text { total cost. }\end{array}$ & $\begin{array}{l}\text { Minimum long term electricity cost } \\
\text { forms the basis for such analysis. }\end{array}$ & {$[122]$} \\
\hline
\end{tabular}

\subsubsection{Artificial intelligence methods}

In these techniques, machine's learning capacity is made utilization of to create designs for the planning of ideal answer for hybrid energy models. Ekren et al. [123] recommended that the execution of ideal purpose of HES was gotten by considering loss of load likelihood on an hourly premise. Another investigation [124] prosed that the Particle Swarm Optimization (PSO) procedure has quicker combination time when contrasted with successive quadratic programming optimization. Vrettos et al. [125] investigations the utilization of batteries for expanding the capability of RES entrance level in a little island. Bansal et al. [126,127] presented a by and large unique methodology where he presented another bio-topography advancement calculation for estimating of free Renewable energy based HES. This has a quicker intermingling time when contrasted with HOMER programming. Studies were directed relying upon the sort of info parameters utilized, a concise review is given in the table beneath.

Table 6: Summary of Artificial Intelligence Methods

\begin{tabular}{lllll}
\hline Input Parameters & $\begin{array}{l}\text { Standalone/ grid } \\
\text { Connected mode }\end{array}$ & $\begin{array}{l}\text { Energy } \\
\text { Sources }\end{array}$ & $\begin{array}{l}\text { Value for which } \\
\text { optimization was } \\
\text { performed }\end{array}$ & Method Used \\
\hline $\begin{array}{l}\text { Hourly mean value of } \\
\text { wind speed, ambient tem- } \\
\text { perature, Solar Radiation }\end{array}$ & Standalone & $\begin{array}{l}\text { PV, Wind } \\
\text { generator and } \\
\text { battery }\end{array}$ & $\begin{array}{l}\text { Cost of installa- } \\
\text { tion }\end{array}$ & $\begin{array}{l}\text { This method verifies that a combined PV-Wind } \\
\text { HES is better than individual PV and Wind } \\
\begin{array}{l}\text { Average of Hour wise } \\
\text { monthly data for wind } \\
\text { speed and solar radiation }\end{array}\end{array}$ \\
$\begin{array}{l}\text { PV, Wind } \\
\text { Hourly average wind } \\
\text { speed }\end{array}$ & Standalone & $\begin{array}{l}\text { generator and } \\
\text { battery }\end{array}$ & $\begin{array}{l}\text { Total System } \\
\text { Cost }\end{array}$ & $\begin{array}{l}\text { Simulated annealing algorithm is used to optimize } \\
\text { the model heuristically. This model can also be } \\
\text { extended in other directions by incorporating in- } \\
\text { flation rate } \\
\text { [129] }\end{array}$ \\
\hline
\end{tabular}

\subsubsection{Hybrid methods}

These are comprised of a blend of at least two distinct procedures, with the goal that the benefits of each can be joined to give an ideal outcome for a particular structure issue. Since it is important to incorporate various factors in assessing the most ideal result, why not do the procedure with numerous strategies so as well as can be expected be gotten in this too. Jadid et al. [131] utilizes a multi-target approach concentrating on cost, condition affect, and imported fuel. He made utilization of fake honey bee province calculation which has great quality and assorted variety of hereditary calculation and molecule swarm improvement. Alsayed et al. [132] utilizes multi target methods to decide the ideal estimating of Photo voltaic-Wind Hybrid Energy framework by utilizing multi criteria choice investigation upgrading approaches. Sensitivity is dissected by weighting criteria systems with various vacillation situation of wind. Meza et al. [133] utilizes multitarget display for age development arranging and explanatory order process which ends up helpful in tackling a multi-target issue. Various different examinations were directed relying upon the sort of info parameters utilized, a concise diagram is given in the table beneath.

Table 7: A summary of Hybrid Methods

\begin{tabular}{lllll}
\hline Input Parameters & $\begin{array}{l}\text { Standalone/ grid } \\
\text { Connected mode }\end{array}$ & Energy Sources & $\begin{array}{l}\text { Value for which opti- } \\
\text { mization was per- } \\
\text { formed }\end{array}$ & Method Used \\
\hline $\begin{array}{l}\text { Hourly wind speed } \\
\text { data }\end{array}$ & Grid connected & $\begin{array}{l}\text { PV generator, bat- } \\
\text { tery bank. }\end{array}$ & $\begin{array}{l}\text { Cost, environmental } \\
\text { impact, imported fuel }\end{array}$ & $\begin{array}{l}\text { A framework is used to solve the multi- } \\
\text { objective model for general expansion, } \\
\text { which also uses analytical hierarchy pro- } \\
\text { cesses. }\end{array}$ \\
$\begin{array}{l}\text { Hourly wind speed, } \\
\text { ambient temperature } \\
\text { and solar radiation }\end{array}$ & $\begin{array}{l}\text { Standalone as well } \\
\text { as grid connected }\end{array}$ & $\begin{array}{l}\text { PV, Wind Genera- } \\
\text { tor, battery bank }\end{array}$ & $\begin{array}{l}\text { Total System cost, En- } \\
\text { ergy Index ratio(EIR) } \\
\text { and emission }\end{array}$ & $\begin{array}{l}\text { multi criteria, multi objective approach } \\
\text { that gives a result set of many designed } \\
\text { objectives }\end{array}$ \\
$\begin{array}{l}\text { Hourly wind speed, } \\
\text { ambient temperature } \\
\text { and solar radiation }\end{array}$ & Standalone & $\begin{array}{l}\text { PV, Wind diesel, } \\
\text { biodiesel Generator, } \\
\text { battery bank }\end{array}$ & $\begin{array}{l}\text { Cost of emission re- } \\
\text { duction, total green- } \\
\text { house gas emission }\end{array}$ & $\begin{array}{l}\text { Large size of diesel fed generator gives } \\
\text { smaller emission where large size of bio- } \\
\text { diesel fed generators gives an opposite ef- } \\
\text { fect }\end{array}$ \\
\hline
\end{tabular}

\subsection{Management of control and energy}

Administration of control and vitality is basic to accomplish most elevated framework unwavering quality and task productivity [137]. Power can be effectively controlled by controller which is fundamental in checking and moderating burden request. A control system is required to decide and relegate dynamic and responsive yield control dispatch from every energy source while keeping its yield voltage and recurrence steady. These systems are sorted into three areas: concentrated, conveyed, cross breed control ideal models and staggered control approach. Each vitality source will have one neighbourhood controller which can decide ideal task of comparing unit based on 
present status. On the off chance that different vitality sources are to be utilized each can work ideally gave a worldwide working choice is accomplished.

\section{Conclusion}

In this paper a far reaching audit on different issues identified with arranging of framework coordinated conveyed generators have been introduced. DG innovations have been talked about with their related benefits and bad marks. A very much detailed arranging issue can be accomplished with an unmistakable comprehension of targets. Hereafter this paper has made an endeavour to examine flow status of research on various arranging targets.

The diagram of the significant viewpoints identified with DG and its effect that DG may have on the task of disseminated systems are additionally talked about. The strategies of ideal situation of DG frameworks and vulnerabilities, improvements procedures/philosophies utilized in ideal arrangement and effects of DG in circulation frameworks are expounded and looked at. Finding a worldwide ideal arrangement of complex multi-target enhancement issues, especially those with numerous neighbourhood optima. One is for the most part looked with a problem between exactness, unwavering quality and computational time.

The paper additionally portrays the issues related with the traditional dissemination framework and the jobs of the DG frameworks in the regular vitality frameworks. The impact of the DG frameworks with the anticipated increment in the quantity of DC fuelled parts uncovers that the DC DG frameworks will before long be for the eventual fate of vitality frameworks. On the other hand, synchronization of the DG units, inrush flows caused by transformers, engines and generators and troublesome in voltage control and framework dependability is as yet the principle difficulties to research in the AC DG frameworks as opposed to the DC DG frameworks.

A reasonable HES relies upon different parameters, for example, innovative, efficient, socio-political and natural components; for considering a large number of these variables while structuring makes the issue mind boggling. It is essential to choose a portion of these components which profoundly rely upon the structuring of HES. Computational devices, for example, HOMER, HYBRID2, IHOGA, RETScreen, and so forth can be utilized for estimating of HES or IRES. For conquering the restriction of a specific estimating procedure some different strategies can be mixed into it for a particular issue, which can be called as half and half philosophy. Among all conceivable control procedures, half and half concentrated and conveyed control ideal models are very appropriate and solid in HES.

It is normal that the expansive scale PV will deliver power at a similar cost and lower than the customary ages in not so distant. The extensive scale PV is the promising power age source because of its spotless and natural neighbourly highlights, be that as it may, have various negative impacts on power framework. From the looked into writing it is apparent that high PV infiltrations on framework are affected by a continuum of variables. The size, area of PV, kind of PV assets, accessibility of sufficient hold in the framework, dispatching and dislodge of ordinary generators by PV, responsive net-metering strategy, and control circles of PV are among the variables seriously influence the effect of PV entrance on framework conduct. From this paper obviously to build the entrances of substantial scale PV later on power frameworks, it is essential to defeat the bottlenecks relating to voltage, recurrence and point dependability and create important guidelines to encourage the mix.

\section{References}

[1] Ackermann T, Andersson G, Soder L, "Distributed generation: a definition". Electrical Power System Research, 2001, 57:195-204

[2] Borges CLT, Falca oDM, "Optimal distributed generation allocation for reliability, losses and voltage improvement". Electrical Power System Research, 2006, 28:413-420.

[3] IEA. Distributed generation in liberalized electricity markets. OECD Publishing, http://dx.doi.org/10.1787/9789264175976-en. [Referred on 10-102018].

[4] Electric Power Research Institute web-page, http://www.epri.com/gg/new gen/disgen/index.html [Referred on 05-01-2017]

[5] Upadhyay, Subho, and M.P. Sharma. "A review on configurations, control and sizing methodologies of hybrid energy systems", Renewable and Sustainable Energy Reviews, 2014

[6] IEEE, Institute of Electrical and Electronics Engineers, 〈http://www.ieee.org [Referred on 06-03-2017]

[7] Priyanka Paliwal, N.P. Patidar, R.K. Nema. "Planning of grid integrated distributed generators: A review of technology, objectives and techniques", Renewable and Sustainable Energy Reviews, 2014

[8] Chambers A., Tulsa Oklahoma, PennWell, "Distributed generation: a nontechnical guide", 2001:283.

[9] Kirubakaran A, Jain S, Nema R K. “A review on fuel cell technologies and power electronic interface”, Renewable Sustainable Energy Rev2009, 13(9):2430-40.

[10] Paska J, Biczel P, Kios M, "Hybrid power systems — an effective way of utilizing primary energy sources", Renewable Energy 2009 34(11):241421.

[11] http://www.distributedgeneration.com [Referred on 08-13-2018]

[12] Chiradeja P, Ramakumar R. “An approach to quantify the technical benefits of distributed generation", IEEETransEnergyConvers2004, 19(4):764 73.

[13] Chiradeja P. "Benefits of distributed generation: a line loss reduction analysis". In: IEEE/PES transmission and distribution conference and exhibition: Asia and Pacific; 2005.p.1-5.

[14] Qian K, Zhou C,Yuan Y,Shi X,Allan M. "Analysis of the environmental benefits of distributed generation". In:IEEE power and energy society general meeting - conversion and delivery of electrical energy in the $21^{\text {st }}$ century, 2008.

[15] Gil HA, Joos G. "Models for quantifying the economic benefits of distributed generation". IEEETransPowerSyst 2008;23(2):327-35.

[16] Waseem I, Pipattanasomporn M, Rahman S. "Reliability benefits of distributed generation as backup source", IEEE power and energy society general meeting, 2009:1-8

[17] Momoh J A, Xia Y, Boswell G.D. "An approach to determine distributed generation benefits in power networks", The 40"h NA power symposium, 2008.p.1-7.

[18] Viral R, Khatod DK. "Optimal planning of distributed generation systems in distribution system: a review". Renewable Sustainable Energy Rev $2012 ; 16: 5146-65$.

[19] Akorede M F, Hizam H, Pouresmaeil E. "Distributed energy resources and benefits to the environment", Renewable Sustainable Energy Rev 2010; 14:724-34.

[20] Jain N, Singh S N, Srivastava S C. "Planning and impact evaluation of distributed generators in Indian context using multi-objective particles warm optimization", IEEE power and energy society general meeting, 2011:1-8.

[21] Chedid R, Rahman S, "Unit sizing and control of hybrid wind - solar power systems", IEEETransEnergyConvers, $1997 ; 12$ (1):79-85.

[22] Wang L, Singh C. "Multi criteria design of hybrid power generation systems based on a modified Particle swarm optimization algorithm". IEEE Trans Energy Convers2009; 24(1):163-72. 
[23] Katsigiannis YA, Georgilakis PS, Karapidakis ES. "Multi objective genetic algorithm solution to the optimum economic and environmental performance. Problem of small autonomous hybrid power systems with renewables" IETRenewPowerGener2010;4(5):404-19.

[24] Doherty R, Outhred H, O’Malley M. "Establishing the role that wind generation may have in future generation portfolios", IEEETransPowerSyst2006;21(3)1415-22.

[25] Barker P. "Determining the impact of distributed generation on power systems: Part 1-Radial distribution systems" IEEE power engineering society summer meeting 2000:1645-56.

[26] Pregelj A, Begovic MM, Rohatgi A, Novosel D. "On optimization of reliability of distributed generation-enhanced feeders", Proceedings of the 36th Hawaii international conference on system sciences, 2003.

[27] Wang L, Singh C. "Reliability-constrained optimum placement of reclosers and distributed generators in distribution networks using an ant colony system algorithm", IEEE Trans Syst Man Cybern Part C Appl Rev 2008; 38(6):757-64.

[28] Gautam D, Mithulananthan N. "Optimal DG placement in deregulated electricity market”, ElectriPowerSystRes 2007; 77(12):1627-36.

[29] Wang C, Hashem Nehrir M. "Analytical approaches for optimal placement of distributed generation sources in power systems". IEEE Trans Power Syst 2004;19(4):2068-76.

[30] Alinejad-Beromi Y, Sedighizadeh M, Bayat MR, M.E. Khodayar. "Using genetic algorithm for distributed generation allocation to reduce losses and improve voltage profile”, The 42nd international universities' power engineering conference; 2007. p. 954-959.

[31] Gozel T, Hakan Hocaoglu M, Eminoglu U, Balikci A. "Optimal placement and sizing of distributed generation on radial feeder with different static load models", International conference on future power systems 2005:2-6.

[32] Lee SH, Park JW. "Selection of optimal location and size of multiple distributed generations by using Kalman Filter algorithm", IEEE Trans Power Syst 2009;24(3):1393-400.

[33] Kumar A, Gao W. "Optimal distributed generation location using mixed integer non-linear programming in hybrid electricity markets", IET Gener Transm Distrib 2010;4(2):281-98.

[34] Carpinelli G, Celli G, Pilo F, Russo A "Distributed generation siting and sizing under uncertainty", IEEE porto power tech proc; 2001.4. 10.1109/PTC.2001.964856.

[35] Méndez Quezada VH, Rivier Abbad J, Gómez San Román T. “Assessment of energy distribution losses for increasing penetration of distributed generation", IEEE Trans Power Syst 2006;21(2):533-40.

[36] Abou El-Ela AA, Allam SM, Shatla MM. "Maximal optimal benefits of distributed generation using genetic algorithms". Electr Power Syst Res 2010;80(7) 869-77.

[37] Ameli MT, Shokri V, Shokri, S. "Using fuzzy logic and full search for distributed generation allocation to reduce losses and improve voltage profile", Proceedings of 2010 international conference on computer information systems and industrial management applications (CISIM); 2010. p. 626-30.

[38] Jizhong Zhu, Kwok Cheung, Hwang D, Sadjadpour A. "Operation strategy for improving voltage profile and reducing system loss", IEEE Transactions on Power Delivery 2010;25(1):390-7.

[39] Mathur HD. "Enhancement of power system quality using distributed generation", Proceedings of 2010 IEEE International Conference on Power and Energy (PECon); 2010. p. 567-72.

[40] Nagliero A, Ricchiuto D, Mastromauro RA, Liserre M. "Management of grid-inverter outages and power quality disturbances in distributed power generation systems", Proceedings of IECON 2010-36th annual conference on IEEE industrial electronics society; 2010. p. $3022-7$.

[41] Singh A, Singh B. "Power quality issues related to distributed energy source integration to utility grids" Proceedings of India conference (INDICON)_-2010; 2010. p. 1-5.

[42] Bojoi RI, Limongi LR, Roiu D, Tenconi A. "Enhanced power quality control strategy for single-phase inverters in distributed generation systems", IEEE Transactions on Power Electronics 2011;26(3):798-806.

[43] Guerrero JM, Blaabjerg F, Zhelev T, Hemmes K, Monmasson E, Jemei S, "Distributed generation: toward a new energy paradigm", industrial electronics magazine. IEEE 2010;4(1):52-64.

[44] Barin Alexandre, Pozzatti Luis F, Canha Luciane N, Machado Ricardo Q, Abaide Alzenira R, Gustavo Arend. "Multi-objective analysis of impacts of distributed generation placement on the operational characteristics of networks for distribution system planning". International Journal of Electrical Power and Energy Systems 2010;32(10):1157-64.

[45] Eto J, Koomey J, Lehman B, Martin NMills E, Webber C, Scoping study on trends in the economic value of electricity reliability to the US economy, LBLN-47911. Berkeley (CA); 2001. p. 134.

[46] IEA: "Distributed generation in liberalized electricity markets". Paris; 2002. p. 128.

[47] Renner H, Fickert L. Costs and responsibility of power quality in the deregulated electricity market. Graz; 1999.

[48] Dondi P, Bayoumi D, Haederli C, Julian D, Suter M. "Network integration of distributed power generation". Journal of Power Sources 2002:1-9.

[49] Pepermans G, Driesen J, Haeseldonckx D, Belmans R, Haeseleer WD. "Distributed generation: definition, benefits and issues". Energy Policy 2006;33(6):787-98.

[50] Marei MI, Abdel-Galil TK, El-Saadany EF, Salama MMA. "Hilbert transform based control algorithm of the DG interface for voltage flicker mitigation". IEEE Transactionson Power Delivery 2005;20(2) [part 1].

[51] Woyte A, Van Thong V, Belmans R, Nijs J. "Voltage fluctuations on distribution level introduced by photovoltaic systems". IEEE Transactions on Energy Conversion 2006;21(1):202-9

[52] Brown RE, Freeman LA’A. “Analyzing the reliability impact on distributed generation”. IEEE_Power Engineering Society Summer Meeting 2001; 2:1013-8.

[53] Borges CLT, Falca o DM. "Optimal distributed generation allocation for reliability, losses and voltage improvement”. Electr Power Syst Res 2006; 28:413-20.

[54] IEEE Application Guide for IEEE Std 1547. In: IEEE standard for interconnecting distributed resources with electric power systems. IEEE Std 1547.2-2008; 2009. p. 1-207.

[55] Méndez Quezada VH, Rivier Abbad J, Gómez San Román T. “Assessment of energy distribution losses for increasing penetration of distributed generation". IEEE Trans Power Syst 2006;21(2):533-40.

[56] Gozel T, Hacaoglu MH. "An analytical method for the sizing and siting of distributed generators in radial distribution systems". Electric Power Systems Research 2009; 79:912-8.

[57] Acharya N, Mahant P, Mitulananthan N. "An analytical approach for DG allocation in primary distribution network". International Journal of Electrical Power and Energy Systems 2006;28(10):669-78.

[58] Mota A, Mota L, Galiana F. "An analytical approach to the economical assessment of wind distributed generators penetration in electric power systems with centralized thermal generation". Latin America Transactions - IEEE (Revista IEEE-America Latina) 2011;9(5):726-31.

[59] Willis HL. "Analytical methods and rules of thumb for modeling DG-distribution interaction". IEEE, Power Engineering Society Summer Meeting 2000;3:1643-4.

[60] Wang C, Nehrir MH. "Analytical approaches for optimal placement of distributed generation sources in power systems. IEEE”, Power Transmission Systems 2004;19(4):2068-76.

[61] Devi AL, Subramanyam B. "Optimal DG unit placement for loss reduction in radial distribution systems-a case study. ARPN", Journal of Engineering and Applied Sciences 2007;2:57-61.

[62] Mahat P, Ongsawkul W, Mithulananthan N. "Optimal placement of wind turbine DG in primary distribution systems for real loss reduction". Proceedings of energy for sustainable development: prospects and issues for Asia,2006. p. 1-6.

[63] Jurado F, Cano A. "Optimal placement of biomass fuelled gas turbine for reduced losses". Energy Conversion and Management 2006; 47:2673-81

[64] Gozel T, Hocaoglu MH, Balikci A. "Optimal placement and sizing of distributed generation on radial feeder with different static load models", Proceedings of the international conference on future power system; 2005. 
[65] Devi AL, Subramanyam B. "Optimal DG unit placement for loss reduction in radial distribution systems - a case study". ARPN—Journal of Engineering and Applied Sciences 2007; 2:57-61.

[66] Osman IH, Kelly JP. "Meta-heuristics: theory and applications". USA: Kluwer Academic publishers; 1996.

[67] Nara K, Ikeda K, Hayashi Y, Ashizawa T. “Allocation of Tabu search to optimal placement of distributed generators". IEEE Power Engineering. Society Winter Meeting 2001; 2:918-23.

[68] Golshan MEH, Arefifar SA. "Optimal allocation of distributed generation and reactive sources considering tap positions of voltage regulators as control variables". European Transactions on Electrical Power 2007;17: 219-39.

[69] Glover F, Taillard E, Taillard E. A user's guide to tabu search. Annals of Operation Research 1993; 41:1-28.

[70] Saidi Mehrabad M, Fattahi P. "Flexible job shop scheduling with Tabu search algorithm", International Journal of Advanced Manufacturing Technology 2007;32:563-70

[71] Kennedy J, Eberhart R. "Particle swarm optimization". IEEE International Conference on Neural networks 1995; 4:1942-8.

[72] Ardakani AJ, Kavyani AK, Pourmousavi SA, "Siting and sizing of distributed generation for loss reduction". International Camivorous plant society 2007.

[73] Parsopoulos KE, Vrahatis MN. "Particle swarm optimization method in multi-objective problems", Proceedings of the 2002, ACM symposium on applied computing. ACM (NY), USA; 2002. p 603-7.

[74] Dorigo M, DiCaro G. "Ant colony optimization: a new meta-heuristic", Proceedings of the 1999 congress on evolutionary computation (CEC 99) vol. 2 ; 1999. p. $1470-7$.

[75] Falaghi H, Haghifam MR. "ACO based algorithm for distributed generations sources allocation and sizing in distribution systems". Proceedings of IEEE Lausanne power technology. University of Tehran; 2007. p. 555-60

[76] El-Arroudi K, Joos G, Kamwa I, McGillis DT. "Intelligent-based approach to islanding detection in distributed generation". IEEE Transactions on Power Delivery 2007;22(2):828-35.

[77] Karaki SH, Kayssi AI, Karaka HS. "Capacitor placement for switching noise reduction using genetic algorithm and distributed computing". Electrical Engineering 2005; 87:11-88.

[78] Carpenelli G, Celli G, Pilo F, Russo A. "Distributed generation siting and sizing under uncertainty". IEEE Power Technology Proceedings 2001;4 p. 1-7.

[79] Celli G, Pilo F. "Penetration level assessment of distributed generation by means of genetic algorithms" Proceedings of the IEEE power systems conference. Clemson, SC; 2002.

[80] Teng JH, Luor TS, Liu YH. "Strategic distributed generator placement for service reliability improvement". IEEE Power Engineering Society Summer Meeting 2002; 2:719-24.

[81] Rebaudendo M, Recorda MS. “A genetic algorithm for floor plan area optimization”. IEEE Transactions on Computer-Aided Design 1996;15(8): 991-1000.

[82] Gadomkar M, Vakilian M, Ehsan M. “A combination of genetic algorithm and simulated annealing for optimal DG allocation in distribution networks", Proceedings of Canadian conference on electrical and computer Engineering. Saskatoon (SK); 2005. p.645-8.

[83] Gadomkar M, Vakilian M, Ehsan M. "A genetic based Tabu search algorithm for optimal DG allocation in distribution networks". J. Electrical Power Components and Systems 2005; 33:1351-62.

[84] Siano P, Harrison GP, Antonio P, Wallace AR. "Strategic placement of distributed generation capacity", Proceedings of 19th international conference on electricity distribution. Vienna; 2007. p. 1-4.

[85] Haghifam MR, Falaghi H, Malik OP. "Risk based distributed generation placement”. IET Generation, Transmission and Distribution 2008;2:25260.

[86] Agbossou K, Kolhe M, Hamelin J, Bose TK. "Performance of a stand-alone renewable energy system based on energy storage as hydrogen". IEEE Trans Energy Conversion. 2004;19(3):633-40.

[87] Sao CK, Lehn PW. "A transformer-less energy storage system based on a cascade multilevel PWM converter with star configuration". IEEE Trans Ind Appl 2008;44(5):1621-30.

[88] Rahman S, Tam K. "Feasibility study of photovoltaic-fuel cell hybrid energy system". IEEE Trans Energy Convers 1988;3(1):50-5.

[89] Sood PK, Lipo TA, Hansen IG. “A versatile power converter for high-frequency link systems”. IEEE Trans Power Electron 1988;3(4):383-90.

[90] HJ Cha, PN Enjeti, "A three-phase AC/AC high-frequency link matrix converter for VSCF applications" Proceedings of the IEEE 34th Annual Power Electronics Specialist Conference 2003 (PESC '03); June 2003, vol. 4, no. 15-19. p. 1971-6.

[91] Nehrir MH, Wang C, Strunz K, Aki H, Ramakumar R, Bing J, “A review of hybrid renewable/ alternative energy systems for electric power generation: configuration, control, and application". IEEE Trans Ind Electron 2011;2(4):392-403.

[92] Kahraman C, Kaya I, Cebi S. "A comparative analysis for multiattribute selection among renewable energy alternatives using fuzzy axiomatic design and fuzzy analytic hierarchy process”. Elsevier J. Energy 2009; 34:1603-16.

[93] Beccali M, Cellura M, Mistretta M. "Decision-making in energy planning: application of the ELECTRE method at regional level for the diffusion of renewable energy technology". Renew Energy 2003; 28:2063-87.

[94] Goletsis Y, Psarras J, Samouilidis JE. "Project ranking in the Armenian energy sector using a multicriteria method for groups". Ann Oper Res 2003; 120:135-57.

[95] Topcu YI, Ulengin F. "Energy for the future: an integrated decision aid for the case of Turkey". Energy 2004; $29: 137-54$.

[96] Ribeiro F, Ferreira P, Araújo M. "Evaluating future scenarios for the power generation sector using a Multi-Criteria Decision Analysis (MCDA) tool: the Portuguese case". Energy 2013;52(1):126-36.

[97] http://eosweb.larc.nasa.gov/sse [Referred on 07-20-2018]

[98] Kimura, Y Onai, Y Ushiyama. L “A demonstrative study for the wind and solar hybrid power system" Proceedings of world renewable energy congress; 1996. p. 895-8.

[99] Beyer GH, Langer C. "A method for the identification of configurations of PV/ wind hybrid systems for the reliable supply of small loads". Sol Energy 1996;57(5):381-91.

[100] Seeling GCH. “A combined optimization concept for the design and operation strategy of hybrid-PV energy systems. Sol Energy 1997;61(2):7787.

[101] Behave AG. "Hybrid solar-wind domestic power generating system: a case study". Renew Energy 1999;17(3):355-8.

[102] Elhadidy MA, Shaahid SM. "Parametric study of hybrid (wind solar diesel) power generating systems". Renew Energy 2000;21(2):129-39.

[103] Knight KM, Klein SA, Duffie JA. "A methodology for the synthesis of hourly weather data". Sol Energy 1991;46(2):109-20.

[104] Gansler RA, Klein SA, Beckman' WA. "Assessment of accuracy of generated meteorological data for use in solar energy simulation studies". Sol Energy 1994;53(3):279-87.

[105] Wahab MA, Essa KSM. "Extrapolation of solar irradiation measurements: case study over Egypt". Renew Energy 1998;14(1-4):229-39.

[106] Gordon M, Reddy TA. "Time series analysis of hourly global horizontal solar radiation". Sol Energy 1988;41(5):423-9.

[107] Gordon JM, Reddy TA. "Time series analysis of daily horizontal solar radiation". Sol Energy 1988;41(3):215-26.

[108] Markvart T. "Sizing of hybrid PV-wind energy systems". Sol Energy 1996;59(4):277-81.

[109] Borowy BS, Salameh ZM. "Methodology for optimally sizing the combination of a battery bank and PV array in a wind/PV hybrid system". IEEE Trans Energy Convers 1996;11(2):367-73.

[110] Karaki SH, Chedid RB, Ramadan R. "Probabilistic performance assessment of autonomous solar-wind energy conversion systems". IEEE Trans Energy Convers 1999;14(3):766-72.

[111] Karaki SH, Chedid RB, Ramadan. "Probabilistic production costing of diesel-wind energy conversion systems". IEEE Trans Energy Convers 2000;15(3):284-9 
[112] Karki R, Billington R. "Reliability/cost implications of PV and wind utilization in small isolated power systems". IEEE Trans Energy Convers $2001 ; 16(4): 368-73$.

[113] Gupta A, Saini RP, Sharma MP. "Steady-state modelling of hybrid energy system for off grid electrification of cluster of villages". Renew Energy 2010;35(1):520-35.

[114] Khatod DK, Pant V, Sharma J. "Analytical approach for well-being assessment of small autonomous power systems with solar and wind energy sources”. IEEE Trans Energy Convers 2010;25(2):535-45.

[115] Makarov YV, Du P, Meyer MCWK, Jin C, Illian HF. "Sizing energy storage to accommodate high penetration of variable energy resources". IEEE Trans Sustain Energy 2012;3(1):34-40

[116] Kaldellis JK, Zafirakis D, Kavadias K. "Minimum cost solution of wind-photovoltaic based stand-alone power systems for remote consumers". Energy Policy 2012;42(1):105-17.

[117] Nikhil PG, Subhakar D. "Sizing and parametric analysis of a stand-alone photovoltaic power plant". IEEE J Photovolt 2013;3(2):776-84.

[118] Xu L, Ruan X, Mao C, Zhang B, Luo Y. “An improved optimal sizing method for wind-solar-battery hybrid power system". IEEE Trans Sustain Energy 2013;4(3):774-84.

[119] Kaldellis JK, Kondili E, Filios A. "Sizing a hybrid wind-diesel stand-alone system on the basis of minimum long-term electricity production cost”. Appl Energy 2006;83(1):1384-403.

[120] Yang H, Lu L, Zhou W. “A novel optimization sizing model for hybrid solar-wind power generation system”. Sol Energy 2007; 81(1):76-84.

[121] Koutroulis E, Kolokotsa D, Potirakis A, Kalaitzakis K. "Methodology for optimal sizing of stand-alone photovoltaic/wind-generator systems using genetic algorithms". Sol Energy 2006; 80(1):1072-88.

[122] S Upadhyay, MP Sharma. "Optimization of hybrid energy system for off-grid application". Proceedings of the 2013 IEEE conference; 2013. p. 343-8.

[123] Ekren O, Ekren BY. "Size optimization of a PV/wind hybrid energy conversion system with battery storage using simulated annealing". Appl Energy 2010; 87(1):592-8.

[124] Pourmousavi SA, Nehrir MH, Colson CM, Wang C. "Real-time energy management of a stand-alone hybrid wind-microturbine energy system using particle swarm optimization”. IEEE Trans Sustain Energy 2010;1(3):193-201.

[125] Vrettos EI, Papathanassiou SA. "Operating policy and optimal sizing of a high penetration RES-BESS system for small isolated grids" IEEE Trans Energy Convers 2011; 26(3):744-56.

[126] Bansal AK, Kumar R, Gupta RA. "Economic analysis and power management of a small autonomous hybrid power system (SAHPS) using biogeography based optimization (BBO) algorithm". IEEE Trans Smart Grid 2013;4(1):638-48

[127] Kumar R, Gupta RA, Bansal AK. "Economic analysis and power management of a stand-alone wind/photovoltaic hybrid energy system using biogeography based optimization algorithm". Swarm Evol Comput 2013;8(1):33-43.

[128] Wang L, Singh C. "Multicriteria design of hybrid power generation systems based on a modified practice swarm optimization algorithm". IEEE Trans Energy Convers 2009; 24(1):163-72.

[129] Katsigiannis YA, Georgilakis PS, Karapidakis ES. "Multi objective genetic algorithm solution to the optimum economic and environmental performance problem of small autonomous hybrid power systems with renewables". IET Renew Power Gener 2010; 4(5):404-19.

[130] Brekken TKA, Yokochi A, Jouanne AV, Yen ZZ, Hapke HM, Halamay DA. "Optimal energy storage sizing and control for wind power applications". IEEE Trans Sustain Energy 2011; 2(1):69-77.

[131] Nasiraghdam H, Jadid S. "Optimal hybrid PV/WT/FC sizing and distribution system reconfiguration using multi-objective artificial bee colony (MOABC) algorithm”. Sol Energy 2012; 86(1):3057-71.

[132] Alsayed M, Cacciato M, Scarcella G, Scelba G. "Multicriteria optimal sizing of photovoltaic-wind turbine grid connected systems". IEEE Trans Energy Convers 2013; 28(2):370-9.

[133] Meza JLC, Yildirim MB, Masud ASM. “A model for the multiperiod multi-objective power generation expansion problem”. IEEE Trans Power Syst 2007; 22(2):871-8.

[134] Dimeas AL, Hatziargyriou ND. “Operation of a multiagent system for microgrid control”. IEEE Trans Power Syst 2005;20(3):1447-55.

[135] Asmus P. "Microgrid, virtual power plants and our distributed energy future". The Electricity Journal 2010;23(10):72-82.

[136] "Smart Grid: reinventing the electric power system". IEEE Power and Energy Society; 2012.

[137] Chakraborty A. "Advancements in power electronics and drives in interface with growing renewable energy resources". Renewable and Sustainable Energy Reviews 2011; 15(4):1816-27. 